\title{
REKONSTRUKSI KEBERAGAMAAN SANTRI JAWA
}

\author{
Ahidul Asror \\ STAIN Jember, Jl. Jumat Mangli No. 94 Jember, \\ ahd_asr@yahoo.co.id
}

\begin{abstract}
This paper distinguishes first of all between Islam as a system of value-transcendental Islam that is-and Islam as socio-cultural phenomenon-sociological Islam that is. The former is about religion as a given system of belief, while the latter is about religious way of life. While touching briefly on the former, the paper will focus a great deal on the latter. It will focus as such on the "constructed Islam" by the Javanese Muslim santris. Employing the social constructive theory, the paper assumes that these santris are active agents in building their own religiosity through what may be called a dialectical moment. Hence, the paper refuses the commonly believed understanding that social facts are completely outside individual awareness in the process of religious construction. By this, the paper attempts to show that Javanese Islam_-sociologically speaking-is none other than the product of santri's cultural and social upbringing.
\end{abstract}

Keywords: Reconstructed Islam, social construction, Javanese santri.

\section{Pendahuluan}

Islam secara teoretis adalah sebuah sistem nilai dan ajaran ilahiyah yang bersifat transenden. Nilai dan ajaran tersebut sepanjang perjalanan sejarah telah membantu para penganutnya memahami realitas dalam rangka mewujudkan pandangan hidup. Pengertian Islam seperti itu lebih bermakna sebagai agama yang diturunkan Allah yang mengajarkan dan mengatur pola hubungan antara manusia dengan Tuhan, manusia dengan manusia, dan manusia dengan alam sekitarnya yang meliputi pokok-pokok kepercayaan dan aturan-aturan hukum yang dibawa melalui utusan yang terakhir, Nabi Muhammad, dan berlaku untuk seluruh umat manusia. ${ }^{1}$ Oleh karena sifatnya yang ideal, maka kapan pun dan dalam situasi apa pun, sistem nilai dan

${ }^{1}$ Lihat bahasan makna Islam dalam Abuddin Nata, Metodologi Studi Islam (Jakarta: Raja Grafindo Persada, 2001), 65. 
ajaran Islam berlaku universal dan tidak akan pernah mengalami perubahan.

Di samping secara teoretis, Islam, sebagai fakta sosiologis, adalah sebuah fenomena sosio-kultural. Di dalam dinamika ruang dan waktu, Islam yang semula berfungsi sebagai subjek pada tingkat kehidupan nyata berlaku sebagai objek dan sekaligus berlaku baginya berbagai hukum sosial. Eksistensi Islam antara lain sangat dipengaruhi oleh lingkungan sosial di mana ia tumbuh dan berkembang. ${ }^{2}$ Di berbagai belahan dunia, Islam pernah mengalami puncak kejayaan peradaban, tetapi tidak dapat dipungkiri bahwa di beberapa tempat lain, Islam justru mengalami dekadensi dan bahkan tenggelam ditelan oleh perubahan zaman. Dinamika Islam dalam sejarah peradaban umat manusia dengan demikian sangat ditentukan oleh pergumulan sosial yang pada akhirnya akan sangat berpengaruh dalam memberi warna, corak, dan karakter Islam. ${ }^{3}$

Membicarakan Islam, lebih khusus lagi tentang warna, corak, dan karakter Islam di dalam dinamika ruang dan waktu tertentu pada hakikatnya adalah berbicara tentang bagaimana pemikiran keislaman direkonstruksi oleh lingkungan sosialnya. Kenyataan membuktikan bahwa dari berbagai hasil penelitian yang dilakukan banyak pakar, ditemukan berbagai corak dan karakter pemikiran keislaman pada berbagai tempat dengan berbagai macam coraknya. Clifford Geertz dalam Islam Observed ${ }^{+}$menemukan perbedaan corak Islam Maroko yang puritan dan Islam Indonesia yang sinkretis. Bahkan, di dalam karya penelitiannya tentang Agama Jawa, Geertz secara lebih khusus membaginya dalam beberapa varian: abangan, santri, dan priyayi. ${ }^{5}$ Tentang gerakan Islam di Indonesia, Deliar Noer juga membagi Islam

\footnotetext{
2 Clifford Geertz menjelaskan masalah ini melalui konsep modes for reality dan modes of reality. Agama pada satu sisi dapat membentuk masyarakat ke dalam cosmic order, tetapi pada sisi lain agama dapat dipengaruhi oleh lingkungan sosialnya. Lihat Brian Morris, Antropologi Agama: Kritik Teori-teori Agama Komtemporer, terj. Imam Khoiri (Yogyakarta: AK Group, 2003), 393.

3 Moeslim Abdurrahman, "Ber-Islam secara Kultural", dalam Islam sebagai Kritik Sosial (Jakarta: Erlangga, 2003), 150.

${ }^{4}$ Geertz dalam studi komparatifnya menjelaskan adanya pengaruh budaya dalam Islam. Lihat Clifford Geertz, Islam yang Saya Amati: Perkembangan di Maroko dan Indonesia, terj. Hasan Basari (Jakarta: YIIS, 1982).

5 Clifford Geertz, Abangan, Santri, Priyayi dalam Masyarakat Jawa, terj. Aswab Mahasin (Jakarta: Pustaka Jaya, 1989), 6.
} 
dalam kategori Islam tradisional dan Islam modernis. ${ }^{6}$ Demikian pula Azyumardi Azra, ketika memetakan gerakan Islam, ia mengenalkan konsep Islam fundamentalisme, modernisme, dan posttradisionalisme. ${ }^{7}$ Berbagai kategori dan variasi Islam yang telah dikenalkan oleh para pakar tersebut membenarkan proposisi bahwa fenomena sosio-kultural yang bernama Islam adalah fenomena yang eksistensinya sangat dipengaruhi lingkungan sosial.

Berpijak dari cara pandang seperti itu, maka penulis mencoba memahami tentang bagaimana Islam dikonstruksi oleh lingkungan masyarakat santri Jawa melalui tradisi keberagamaan populer. Rekonstruksi Islam dalam tulisan ini dipahami sebagai terbentuknya corak Islam melalui proses interaksi antara Islam dengan tradisi masyarakat lokal. Bingkai perspektif yang digunakan untuk menganalisis fenomena sosio-kultural di sini menggunakan bingkai pendekatan konstruktivisme. Asumsi teori konstruktivisme bukan saja menempatkan posisi individu dalam masyarakat sebagai subjek yang mampu membangun realitas sosio-kulturalnya, tetapi dengan realitas objektif yang telah diciptakan itu, mereka menggunakannya sebagai medium simbolik dan tata cara berinteraksi dalam rangka mempertahankan eksistensinya.

Secara lebih khusus, perspektif teori yang digunakan di dalam tulisan ini adalah perspektif teori konstruktivisme yang dikenalkan oleh Peter L. Berger dan Thomas Luckmann ${ }^{8}$ yang keberadaannya merupakan kelanjutan dari teori fenomenologi. Perspektif ini berbeda dengan perspektif teori dalam ilmu sosial yang menempatkan manusia sebagai korban dari dunia sosialnya. Teori yang termasuk di dalam kategori fenomenologi lahir sebagai tandingan terhadap teori yang berada dalam paradigma fakta sosial yang digagas Emile Durkheim. Paradigma ini berasumsi bahwa fakta sosial adalah sesuatu yang harus dinyatakan sebagai apa yang berada di luar individu (external). Fakta sosial itu bersifat memaksa terhadap individu (coercive).

${ }^{6}$ Deliar Noer, Gerakan Modern Islam di Indonesia 1900-1942 (Jakarta: LP3ES, 1980).

7 Azyumardi Azra, Pergulatan Politik Islam dari Fundamentalisme, Modernisme, bingga PostTradisionalisme (Jakarta: Paramadina, 1996), i-xii

8 Peter L. Berger dan Thomas Luckmann, Tafsir Sosial atas Kenyataan: Risalah tentang Sosiologi Pengetahuan, terj. Hasan Basari (Jakarta: LP3ES, 1990).

${ }_{9}$ George Ritzer, Sosiologi Ilmu Pengetahuan Berparadigma Ganda, terj. Alimandan (Jakarta: Rajawali Press, 1985), 102. 
Masyarakat santri Jawa yang dijadikan sebagai objek kajian di dalam tulisan ini lebih disebabkan oleh karena di dalam lingkungan mereka masih ditemukan ragam praktik keberagamaan Islam populer yang di dalamnya menyimpan semangat dan nilai-nilai yang menjadi spirit bagi perkembangan Islam Nusantara. Untuk menampilkan kembali semangat Islam Nusantara dengan berbagai warna dan corak yang ada di dalamnya tentu tidak lepas dari sejarah penyebaran Islam awal yang dimainkan walisongo, di mana mereka telah menyebarluaskan Islam di Jawa. Hal itu menjadi argumentasi pentingnya pembahasan tentang bagaimana rekonstruksi pemahaman keislaman dalam tradisi keberagamaan populer yang terjadi di lingkungan masyarakat santri Jawa.

\section{Hubungan Islam dan Tradisi Lokal}

Topik kajian tentang Islam Indonesia telah banyak ditulis oleh para pakar. Sebagian besar di antara mereka berpendapat bahwa dalam membicarakan tentang Islam Indonesia, khususnya Jawa, perlu kiranya mengenal karya monumental Clifford Geertz, The Religion of Java, yang ditulis pada awal tahun 1960-an. Meski telah berumur kurang lebih setengah abad dan telah banyak mendapat kritik, tetapi karya Geertz tetap menjadi kajian menarik bagi para pakar dalam memulai penelitian tentang Islam Indonesia. Arti penting karya itu bukan saja terletak pada kecemerlangan Geertz menyajikan data empiris mengenai keberagamaan masyarakat Jawa tetapi juga karena pandangan kategorisnya tentang masyarakat Jawa ke dalam tipologi: abangan, santri, dan priyayi. Dengan tipologi itu, Geertz telah mengembangkan pandangan bahwa Islam yang dipeluk orang Jawa adalah artifisial. Islam Jawa sejatinya adalah Islam yang dilumuri dengan praktik-praktik sinkretisme. ${ }^{10}$ Pengaruh Islam dikatakannya tidak terlalu besar. Agama ini hanya memberikan sentuhan kulit luar budaya Animisme, Hindu dan Budha yang telah berakar kuat dan dipeluk oleh hampir seluruh masyarakat Jawa.

\footnotetext{
${ }^{10}$ Menurut Geertz, di Jawa, Islam tidak pernah menyusun sebuah bangunan peradaban, melainkan hanya menyelaraskannya. Bagi masyarakat Jawa, Islam hanyalah sebuah tradisi asing yang dipeluk dan dibawa oleh para pedagang di pesisir utara. Melalui sebuah proses asimilasi, Islam secara perlahan hanya berhasil membentuk kantong-kantong masyarakat di sejumlah kota besar dan kalangan petani kaya. Komunitas Muslim seperti disebutkan di bagian pertama itulah yang di kemudian hari membetuk sebuah sinkretisme dengan menekankan aspek-aspek kebudayaan Islam. Lihat Geertz, Abangan, Santri, 7.
} 
Konsep sinkretisme dalam karya Geertz telah mewartakan kepada para peneliti Islam di Indonesia pada masa-masa berikutnya, khususnya tentang bagaimana pola interaksi yang dibangun antara Islam dengan budaya masyarakat lokal. Geertz dalam konsep sinkretisme meletakkan posisi Islam sebagai komponen yang kurang penting dalam konstruksi agama Jawa. Pandangan ini sekaligus menempatkan Geertz sebagai ilmuan yang paling sering dibicarakan dalam kajian tentang Islam di Indonesia sekaligus menjadi sasaran kritik. Harsja W. Bachtiar, misalnya, mengemukakan pandangan bahwa penjelasan Geertz tentang tipologi masyarakat terasa sangat membingungkan. Menurutnya, orang Jawa bukan semata-mata orang Jawa, melainkan mempunyai kedudukan tertentu yang di dalamnya menunjukkan rangkaian model perilaku tertentu yang tidak selalu merefleksikan praktik keberagamaan. Artinya, perilaku orang Jawa tidak seharusnya selalu ditafsirkan dengan mengacu kepada agama, tetapi lebih memungkinkan ditafsirkan dari segi adat yang berlaku secara normatif pada situasi di mana orang Jawa hidup. ${ }^{11}$

Kritik terhadap Geertz juga dikemukakan Zaini Muchtarom. Analisis Geertz secara panjang lebar tentang sistem religius dan pandangan dunia orang Jawa melahirkan beberapa kerumitan yang kadang juga sangat mengacaukan. Ketiga golongan yang dikemukakan dalam tiga tipologi masyarakat Jawa oleh Geertz merupakan tiga pandangan dunia, gaya hidup, varian, dan tradisi religius yang berlaku sangat khusus dan ketat. Muchtarom di sini sangat keberatan dengan pendapat yang dikemukakan oleh Geertz, di mana setiap tipologi tersebut menitikberatkan pada salah satu di antara tiga segi khusus sinkretisme religius Jawa, yaitu segi Animisme, Hinduisme-Budhisme, dan Islam. ${ }^{12}$

Selanjutnya, berbagai hasil penelitian lapangan yang mengkaji interaksi antara Islam dengan budaya lokal juga telah banyak mengkritik pandangan Geertz. Dalam penelitian di Keraton Yogyakarta, Mark R. Woodward secara tegas mengatakan bahwa karya Geertz telah mendominasi wacana atas berbagai karya tentang "Islam" dan "Jawa" yang telah dikonstruksi sebagai dua entitas yang saling berlawanan, berbeda, terpisah dan tidak mungkin bersenyawa.

11 Harsja W. Bachtiar, "The Religion of Java: Sebuah Komentar", dalam Geertz, Abangan, Santri, 527.

12 Zaini Muchtarom, Islam di Jawa dalam Perspektif Santri dan Abangan (Jakarta: Salemba Diniyah, 2002), 5-6. 
Konstruksi demikian telah melahirkan sebuah pandangan bahwa Islam Jawa merupakan sebuah penyimpangan dari ortodoksi Islam. Tesis utama Woodward tentang Islam Jawa adalah Islam yang tidak menyimpang, melainkan merupakan varian Islam sebagaimana ditemukan tentang adanya Islam Maroko, Islam India, Islam Suriah dan seterusnya. Keunikan Islam Jawa menurut Woodward bukan terletak pada aspek dipertahankannya budaya agama pra-Islam, melainkan lebih disebabkan oleh karena adanya konsep tentang bagaimana membentuk manusia sempurna sesuai dengan aturanaturan sosial yang berlaku di masyarakat. ${ }^{13}$

Peneliti lain yang juga mengkritik Geertz adalah Robert W. Hefner. Penelitian Hefner di daerah Tengger Jawa Timur menemukan konsep ambiguitas dan multivokalitas dalam tradisi masyarakat. Tradisi ritual dalam masyarakat Tengger dieksploitasi untuk memungkinkan bagi orang-orang yang mempunyai perbedaan latar kultur dan orientasi agar dapat hadir bersama. Bagian penting dari berbagai penyelenggaraan ritual pada masyarakat Tengger adalah tidak terjadinya decoding di tengah-tengah masyarakat. Kebudayaan regional (yang masih diakui sebagai Jawa) tumbuh subur tanpa rintangan menurut model superiornya; dan tidak ada lagi perbedaan, ${ }^{14}$ yang menghubungkan antara kalangan petani dengan kalangan yang tinggal di istana. Temuan ini bukan saja meruntuhkan tipologi masyarakat yang dibuat Geertz, tetapi secara khusus dalam ruang lingkup keagamaan terdapat kompromi yang terjadi antara Islam dengan tradisi yang merupakan kearifan masyarakat lokal.

Niels Mulder dalam penelitiannya juga membahas tentang interaksi Islam dengan budaya lokal. ${ }^{15}$ Dalam tulisannya yang menggunakan cara pandang lokalisasi untuk menolak konsep sinkretisasi Geertz, Mulder mengatakan bahwa agama di Asia Tenggara adalah agama yang telah mengalami proses lokalisasi. Pandangan seperti ini ingin melihat adanya pengaruh kekuatan budaya lokal terhadap agama-agama yang datang kepadanya. Agama asinglah yang kemudian menyerap tradisi. Bukan sebaliknya, budaya lokal atau

13 Mark R. Woodward, Islam Jawa: Kesaleban Normativ versus Kebatinan, terj. Hairus Salim (Yogyakarta: LKiS, 1999), 93.

14 Robert W. Hefner, Hindu Javanese: Tengger Tradition and Islam (Princenton: Princenton University Press, 1985), 39.

15 Niels Mulder, Agama Hidup Sehari-hari dan Perubahan Budaya, terj. Satrio Widiatmoko (Jakarta: Gramedia Pustaka Utama, 1999). 
agama lokal yang menyerap agama asing. Dalam contoh agama Islam di Indonesia, Mulder melihat bahwa Islamlah yang kemudian menyerap keyakinan atau kepercayaan lokal sehingga yang terjadi adalah proses menarik ajaran lokal ke dalam agama-agama besar lainnya. Di dalam proses lokalisasi ini, unsur keyakinan asing harus menemukan lahannya dalam kebudayaan lokal dan unsur asing tersebut dapat dicangkokkan. Tanpa adanya unsur lama yang serasi dengan keyakinan asing, maka keyakinan lama tidak akan dapat meresap sedemikian jauh ke dalam tradisi keagamaan tersebut. Islam Jawa hakikatnya adalah Islam yang menyerap tradisi lokal.

Studi lain yang menghasilkan pandangan kritik terhadap Geertz juga dilakukan Andrew Beatty. Dalam deskripsinya tentang masalah slametan di Banyuwangi, Beatty menemukan sebuah realitas yang di dalamnya terdapat berbagai latar belakang golongan sosio-kultural dan ideologi yang berbeda. Mereka ini ternyata dapat bersatu di dalam satu tradisi yang disebut slametan. ${ }^{16}$ Realitas ini menurut Beatty merupakan sebuah interkoreksi antara sinkretisme sebagai proses sosial, multivokal ritual, dan hubungan antara Islam dengan tradisi lokal.

Kritik terhadap pandangan Geertz juga dilakukan oleh Nur Syam dalam penelitiannya tentang masyarakat nelayan di Tuban Jawa Timur. ${ }^{17}$ Syam mengkritik konsep sinkretisme Geertz yang dianggap mengabaikan adanya dialog antara Islam dengan budaya lokal. ${ }^{18}$ Studi yang dilakukan oleh Syam menghasilkan sebuah konsep baru yang disebut dengan istilah Islam kolaboratif, yaitu realitas keberagamaan yang mengadopsi unsur lokal yang tidak bertentangan dengan Islam dan menguatkan ajaran Islam melalui proses transformasi secara terus-menerus.

Berbagai studi yang telah dilakukan oleh banyak pakar di atas mengantarkan kepada satu kesimpulan bahwa Islam yang berkembang di Indonesia, khususnya di wilayah Jawa, adalah sebuah fenomena unik. Keunikan itu dapat diidentifikasi melalui kemampuan masyarakat Jawa melakukan rekonstruksi pemikiran keislaman melalui

\footnotetext{
16 Secara umum slametan adalah menciptakan keadaan sejahtera, aman, bebas dari gangguan makhluk halus. Lihat Andrew Beatty, Variasi Agama di Jawa: Suatu Pendekatan Antropologi, terj. Achmad Fedyani Saifuddin (Jakarta: Raja Grafindo Persada, 1999), 43.

17 Nur Syam, "Tradisi Islam Lokal Pesisiran: Studi Konstruksi Sosial Upacara pada Masyarakat Pesisir Palang Tuban Jawa Timur" (Disertasi--Universitas Airlangga, Surabaya, 2003).

${ }^{18}$ Ibid., 327.
} 
interaksi Islam dengan tradisi masyarakat lokal tanpa kehilangan arah ortodoksi Islam. Sebagaimana pandangan beberapa pakar yang melakukan studi tentang Islam Indonesia, Islam Jawa bukan sesuatu yang asing, bahkan perlu dicatat sebagai prestasi mengagumkan. ${ }^{19}$

\section{Pendekatan Teori Konstruksi Sosial}

Belum ada laporan penelitian yang menyatakan ada sebuah masyarakat yang tidak memiliki konsep tentang agama. Meski peristiwa perubahan sosial mengubah orientasi dan makna agama, tetapi hal itu tidak serta merta berhasil meniadakan eksistensinya dalam masyarakat. Kajian tentang agama bahkan terus berkembang dan menjadi kajian yang sangat urgen. ${ }^{20}$ Oleh karena universalitas agama dalam masyarakat, maka kajian tentang masyarakat tidak akan lengkap jika tidak menyertakan kajian tentang agama. Kajian politik, ekonomi dan perubahan sosial lainnya di dalam masyarakat sering melupakan keberadaan agama sebagai salah satu faktor yang determinan sehingga tidak mengherankan jika kajian-kajian tersebut belum mampu menggambarkan realitas sosial yang sungguh-sungguh terjadi.

Pada posisi itulah, antropologi sebagai ilmu yang mempelajari manusia menjadi sangat penting untuk memahami agama. Antropologi mempelajari tentang manusia dan segala perilaku mereka untuk dapat memahami perbedaan kebudayaan manusia. Dengan bekal pendekatan holistik dan komitmen akan pemahaman tentang manusia, sesungguhnya antropologi merupakan ilmu yang penting untuk mempelajari agama dan interaksi sosialnya dengan berbagai budaya. Jika demikian, maka memahami Islam yang telah berproses dalam sejarah dan budaya tidak lengkap jika tanpa memahami manusia yang di dalam Islam ditempatkan dalam posisi sebagai khalifah. Posisi ini mengindikasikan bahwa sesungguhnya persoalan utama dalam memahami agama Islam adalah bagaimana memahami manusia. Persoalan lain yang dialami manusia sesungguhnya adalah persoalan agama yang sebenarnya. Ini berarti pergumulan dalam kehidupan kemanusiaan pada dasarnya adalah pergumulan keagamaannya. Dengan kata lain, realitas keagamaan yang sesungguhnya adalah realitas kemanusiaan yang mengejawantah dalam

19 Marshall Hodgson, The Venture of Islam, Vol. 2 (Chicago: The University of Chicago Press, 1974), 551.

20 Roland Robinson, Agama dalam Analisa dan Interpretasi Sosiologis, terj. Achmad Fedyani Saifuddin (Jakarta: Rajawali, 1988), xvii. 
dunia karenanya antropologi diperlukan untuk memahami realitas kemanusiaan dan memahami Islam yang dipraktikkan.

Disadari bahwa kajian tentang agama akan mengalami kesulitan karena kajian ini bertugas meneliti sesuatu yang terkait dengan kepercayaan (belief) yang ukuran kebenarannya terletak pada keyakinan normatif. Namun, tradisi antropologi dalam mengkaji agama berkembang dengan pesat terutama pada abad ke 16-17. EvansPiritchard adalah salah seorang antropolog terkemuka di Inggris yang mengatakan bahwa dilema kajian tentang agama adalah bahwa pemahaman tentang realitas agama tidak akan sepenuhnya dapat dipahami kecuali oleh orang yang mengamalkan agama itu sendiri. Hal ini pernah ia rasakan ketika sedang meneliti masyarakat Azande, ${ }^{21}$ di mana ilmu ghaib memainkan peranan penting pada hampir setiap aktivitas sosial mereka. Di sinilah perlunya digunakan sikap empati.

Kesulitan mempelajari agama dengan pendekatan antropologi yang mempelajari wacana, pemahaman dan tingkah laku manusia dalam hubungannya dengan ajaran agama, dirasakan juga oleh mereka yang beragama. Kesulitan itu terjadi karena ketakutan untuk membicarakan masalah agama yang sakral dan bahkan sangat mungkin dianggap tabu. Persoalan akan semakin bertambah karena pemahaman bahwa agama bukan konstruksi manusia, tetapi agama lebih dipahami sebagai sesuatu yang berasal dari wahyu suci Tuhan. Sebagai akibat pemahaman semacam ini, maka realitas keagamaan dianggap atau diyakini sebagai sebuah ketentuan yang baku dan tidak perlu lagi untuk dipahami.

Dalam pembahasan tentang rekonstruksi Islam di lingkungan masyarakat santri Jawa ini, penulis menggunakan pendekatan teori yang dipergunakan Peter L. Berger bersama rekannyaThomas Luckmann melalui teori konstruksi sosial. ${ }^{22}$ Melalui teorinya, mereka menggambarkan proses di mana melalui tindakan dan interaksinya, manusia menciptakan secara ekstensif sebuah kenyataan yang dimiliki bersama, yang dialami secara faktual objektif dan penuh arti secara

21 Azande adalah masyarakat Sudan yang dalam era pra-kolonial diorganisir ke dalam sejumlah kerajaan terpisah-pisah, masing-masing diatur oleh seorang anggota klan aristokratik. Keyakinan terhadap spirit-pencipta tertinggi Mbori dan hantu nenek moyang (atoro) adalah hal penting bagi Azande, khususnya bagi konteks domistik. Namun, keyakinan yang menonjol dalam kebudayaan Azande adalah keyakinan dalam pengobatan (magis) dan ilmu ghaib. Lihat Morris, Antropologi Agama, 237.

22 Berger dan Luckmann, Tafsir Sosial atas Kenyataan, 28-65. 
subjektif. Teori Berger dan Luckmann yang bekerja dalam orientasi fenomenologi sesungguhnya merupakan kritik atas paradigma fakta sosial Durkheim. Berger dan Luckmann lebih mengedepankan pandangan dialektik ketika melihat hubungan antara manusia dan masyarakat; manusia menciptakan masyarakat demikian pula masyarakat menciptakan manusia. ${ }^{23}$

Berger mendefinisikan kebudayaan sebagai totalitas produk manusia bukan sekadar berupa material dan non-material ${ }^{24}$ tetapi juga berupa refleksi di dalam isi kesadaran manusia yang dijadikan sebagai pedoman atau alat interpretasi keseluruhan tindakan. Refleksi di dalam isi kesadaran tersebut merupakan seperangkat kognisi, sedang aspek material dan non-material adalah kelakuan dan produk kelakuan. Pernyataan di atas berbeda dengan gagasan populer dalam tradisi antropologi fungsional yang melihat refleksi isi kesadaran sekadar ide yang berada di luar kepala individu. ${ }^{25}$

Agama sebagai sistem kebudayaan yang diartikan Berger sebagai suatu usaha manusia untuk membentuk kosmos keramat, ${ }^{26}$ dengan demikian, juga mengandung unsur konstruksi manusia, sebab agama bukan sekadar kelakuan dan produk kelakuan. Realitas keberagamaan selalu diwarnai oleh lingkungan sosial di mana pengetahuan itu diperoleh, ditransmisikan atau dipelajari. Artinya, manusia tidak akan dapat menangkap realitas, kecuali dalam kerangka proses sosial yang terlibat. Hal tersebut tertuang dalam pandangan Berger dan Luckmann yang dikenal dengan istilah eksternalisasi, objektivikasi dan internalisasi ketika melihat hubungan antara manusia, masyarakat dan agama.

Pertama, agama mengalami proses eksternalisasi ketika agama menjadi norma yang berfungsi mengontrol tindakan masyarakat. Eksternalisasi merupakan momen adaptasi diri dengan dunia sosiokultural. Oleh karena adaptasi merupakan proses penyesuaian, maka dimungkinkan adanya variasi tindakan. Melalui eksternalisasi,

\footnotetext{
23 Peter L. Berger, Langit Suci: Agama sebagai Realitas Sosial, terj. Hartono (Jakarta: LP3ES, 1991), 4-5.

${ }^{24}$ Ibid., 8.

25 Syam, “Tradisi Islam Lokal Pesisiran”, 18-19.

${ }^{26}$ Agama adalah kosmisasi dalam suatu cara yang keramat (sakral). Kata "keramat" dimaksudkan sebagai suatu kualitas kekuasaan yang misterius dan menakjubkan, bukan dari manusia tetapi berkaitan dengannya, yang diyakini berada dalam objekobjek pengalaman tertentu. Lihat Berger, Langit Suci, 32.
} 
masyarakat merupakan produk manusia. Kedua, agama mengalami proses objektivikasi ketika berada di luar diri manusia, seperti ketika agama berada di dalam teks-menjadi tata nilai. Objektivikasi merupakan momen interaksi sosial di dalam dunia intersubjektif yang dilembagakan. Melalui objektivikasi, masyarakat menjadi realitas sui generis, unik. Ketiga, agama mengalami proses internalisasi ketika realitas objektif itu ditarik kembali ke dalam diri individu sehingga seakan-akan menjadi realitas subjektif. Melalui internalisasi, manusia merupakan produk masyarakat. Teori konstruksi sosial dengan demikian adalah teori yang mengedepankan cara berfikir secara dialektis.

\section{Rekonstruksi Keberagamaan Santri Jawa}

Bagaimana rekonstruksi keberagamaan di lingkungan masyarakat santri Jawa dalam perspektif teori konstruksi sosial? Sebelum menjawab pertanyaan ini, perlu mulai diketahui lebih dulu, siapa yang disebut "Santri Jawa" pada tulisan ini? Geertz dalam The Religion of Java membagi masyarakat Jawa dalam tipologi abangan, santri, dan priyayi. Dalam uraian khusus tentang varian santri, Geertz telah terjebak oleh sumber-sumber yang berkembang dari kalangan modernis, ${ }^{27}$ terbukti ia kurang memberikan apresiasi terhadap karakteristik Islam lokal. Uraian Geertz tentang varian santri Jawa lebih diorientasikan untuk menjelaskan kalangan santri modernis yang hidup di wilayah perkotaan daripada kalangan santri yang hidup di wilayah pedesaan Jawa.

Dalam menyikapi masalah tersebut, Marshall Hodgson pernah menyindir Geertz yang selalu menggemakan pemakaian istilah "puritan" untuk merujuk kepada mazhab pemikiran Islam modern tertentu. ${ }^{28} \mathrm{Hal}$ ini tampak ketika Geertz menjelaskan mengenai ciri-ciri umum Islam dengan cara selalu menelusuri sejarah sharî‘ah dan kurang memperhatikan pentingnya peran sufisme dalam proses

27 Geertz dalam hal ini mengacu kepada Muhammad Abduh, sosok pembaru puritan yang melakukan pendobrakan terhadap struktur pemikiran tradisional dan pada saat yang sama menganjurkan adanya modernisasi. Lihat Geertz, Abangan, Santri, 187-188.

28 Pemahaman Geertz tentang Islam tampak dipengaruhi oleh alur pemikiran modern yang tidak hanya menggemakan pentingnya penolakan terhadap masuknya unsur-unsur asing dalam Islam tetapi juga pentingnya kembali kepada ajaran Islam yang asli (al-Qur'ân-Hadîth). Lihat Ibid., 66. 
penyebaran Islam di Jawa. ${ }^{29}$ Padahal, dalam kurun waktu cukup lama, di Jawa sudah berkembang tradisi besar Islam. Tradisi ini lahir sebagai hasil strategi para penyebar Islam awal dalam menyikapi proses akulturasi dengan budaya masyarakat lokal. Tradisi besar yang kemudian dikenal dengan istilah "tradisi pesantren" itu menjadi babak baru dalam sejarah Jawa karena berhasil menjadi budaya tandingan bagi masyarakat pedalaman, Hindu-Jawa yang digawangi kalangan istana dan keraton Jawa. Dengan lahirnya budaya tandingan yang berkembang di pedesaan, maka Islam Jawa bukan lagi tampil sebagai subkultur, tetapi telah berkembang sedemikian rupa menjadi sebuah tradisi besar (great tradition). ${ }^{30}$

Geertz juga kurang jeli membaca sejarah penyebaran Islam Jawa yang dirintis oleh walisongo dan dilanjutkan para ulama Demak, Mataram hingga Kartasura yang telah berkembang secara pesat karena berhasil mengintegrasikan diri dengan kebudayaan yang ada di sekelilingnya. ${ }^{31}$ Semua sistem pengetahuan dan kebudayaan tersebut diapresiasi secara setara, yang kemudian diolah menjadi kebudayaan baru yang relevan. ${ }^{32}$ Sayang, proses tersebut mengalami kemandekan setelah terjadi hubungan antara Islam Jawa dengan pusatnya, Mekah, terutama setelah terjadi transportasi modern sejak masa awal datangnya Belanda. Masa-masa setelah itu ditandai oleh munculnya gerakan pemurnian Islam yang berusaha menolak warna lokal yang diinspirasi kaum Wahabi yang sangat gencar menolak apresiasi adat dan tradisi lokal. Gerakan inilah yang banyak menginspirasi Geertz dalam melihat ciri Islam.

Hanya komunitas Islam tradisional berbasis pesantren yang bisa membendung arus puritanisasi itu. Pesantren dalam hal ini memposisikan diri sebagai cagar budaya yang mengembangkan tradisi

\footnotetext{
${ }^{29}$ Geertz, Islam yang Saya Amati, 32.

30 Joko Suryo, "Tradisi Santri dalam Historiografi Jawa: Pengaruh Islam di Pesisir Utara Jawa", dalam dari Samudra Pasai ke Yogyakarta, Sunaryo Purwo Sumitro (ed.) (Jakarta: Yayasan Masyarakat Sejarawan Indonesia, 2002), 15.

31 Hasan Muarif Ambary, Menemukan Peradaban Jejak Arkeologis dan Historis Islam Indonesia (Jakarta: Logos Wacana Ilmu, 1998). Lihat juga Ridin Sofwan, et al., Islamisasi di Jawa: Walisongo Penyebar Islam di Jawa menurut Penuturan Babad (Yogyakarta: Pustaka Pelajar, 2000).

32 Abdul Rahman Haji Abdullah, "Pemikiran Islam Tradisional di Nusantara: Pertumbuhan dan Perkembangannya", dalam Pemikiran Umat Islam di Nusantara: Sejarah Perkembangannya hingga Abad ke-19 (Selangor: Dewan Bahasa dan Pustaka, 1990), 102.
} 
sendiri, baik tradisi pemikiran keilmuan, berbahasa maupun tata cara berpakaian. Dengan posisi demikian itu, maka pluralitas pemahaman Islam di Nusantara dapat dipertahankan, dan relasi Islam dengan berbagai komunitas lain (seperti komunitas adat dan agama lain) dapat berlangsung di bawah prinsip toleransi yang dikembangkan kalangan Islam tradisional. Sikap toleransi itu melahirkan tradisi yang berisi unsur Islam. ${ }^{33}$ Strategi ini, yang dalam perkembangannya dianggap sangat akomodatif, merupakan kearifan para penyebar Islam dalam menyikapi proses akulturasi. Komunitas Islam inilah yang disebut di dalam tulisan ini sebagai santri Jawa.

Peran yang dimainkan santri Jawa cukup signifikan sejak tumbuh dan berkembangnya Islam di wilayah Nusantara. ${ }^{34}$ Mereka mempunyai karakteristik khusus di dalam memandang tradisi. Santri Jawa mempunyai ciri akomodatif terhadap praktik-praktik tradisi masyarakat lokal karena pola inilah yang memberi sumbangan berarti bagi proses awal pengislaman yang berjalan relatif tanpa jalan kekerasan. Pola ini sejak semula mendapat inspirasi dari penganjur Islam awal (walisongo) oleh karena adanya kesesuaian dengan masyarakat yang sebagian besar berbasis massa sebagai petani yang hidup di wilayah pedesaan, kemudian melahirkan tuduhan sebagai corak Islam yang telah mengalami stagnasi. ${ }^{35}$ Selain itu, orientasi keberagamaan santri Jawa sangat menghargai warisan klasik yang terkristalisasi di dalam ajaran-ajaran mazhab. Di dalam menyikapi soal pembaruan Islam, santri Jawa dengan karakternya tetap berupaya menyelaraskannya dengan warisan tradisi yang berkembang pada masyarakat lokal.

Setelah diketahui tentang siapa yang disebut "Santri Jawa" di dalam tulisan ini, maka sampai pada pembahasan tentang bagaimana perspektif teori konstruksi sosial memahami rekonstruksi Islam melalui tradisi keberagamaan populer di lingkungan masyarakat santri Jawa? Sebagaimana dijelaskan pada perspektif kajian, gagasan inti dari teori konstruksi sosial yang dikenalkan oleh Peter L. Berger dan Thomas Luckmann adalah gagasan tentang konstruksi kenyataan sosial (social reality construction), yaitu bahwa melalui tindakan dan

${ }^{33}$ Ibid., 101.

34 Ibid., 94.

35 Pendapat ini bertentangan dengan Gibb yang berpandangan bahwa tidak ada aliran filsafat dan agama yang benar-benar mengalami kemandekan. Lihat H.A.R. Gibb, Modern Trend in Islam (Illionis: The University of Chicago, 1947), 1-2. 
interaksinya, manusia menciptakan terus menerus sebuah kenyataan yang dimilikinya bersama, yang dialaminya secara faktual objektif, tetapi mempunyai makna subjektif. Gasasan ini terangkum dalam proses dialektik melalui momen eksternalisasi, objektivikasi, dan internalisasi, sebagaimana telah dijelaskan pada bagian sebelumnya.

Greag Fealy dalam artikelnya mencatat bahwa variasi tradisi santri Jawa populer yang terus dikokohkan di kalangan mereka adalah praktik-praktik lokal, seperti ritual lingkaran hidup, ritual selametan, ziarah kubur, muludan, tahlil dan lain sebagainya. ${ }^{36}$ Dalam tulisan ini, tidak mungkin semua tradisi populer yang berkembang di lingkungan santri Jawa dianalisis satu persatu melalui perspektif konstruksi sosial. Penulis hanya mengambil satu sampel, yaitu praktik ziarah kubur. ${ }^{37}$

Di lingkungan masyarakat santri Jawa, ziarah kubur tidak sematamata merupakan peneguhan identitas kultural, tetapi secara normatif diajarkan dalam Islam, sebagaimana hadîth Nabi: Kuntu nahaytukum 'an ziyârat al-qubûr fa zûrubâ. Hadîth ini menjelaskan, semula Nabi memang melarang umatnya berziarah kubur karena dikhawatirkan merusak akidah umat yang masih rentan, tetapi setelah dirasa keteguhan akidah umat semakin kuat, maka Nabi pun kemudian memerintahkan kepada umatnya melakukan ziarah kubur. Ziarah kubur dalam Islam faedahnya antara lain dapat mengingatkan orang hidup kepada kematian sehingga dapat diambil pelajaran darinya (kafâ bi al-mawt maw'izab). Di kalangan santri Jawa, ziarah kubur selain dipercaya faedahnya sebagai pengingat bagi yang hidup juga mempunyai tempat tersendiri di dalam kultur Jawa, yaitu kebiasaan orang Jawa yang selalu menaruh hormat kepada leluhur-leluhurnya. Bahkan, pada waktu-waktu tertentu, seperti datangnya bulan Ramadan, berziarah ke makam leluhur menjadi bagian integral tradisi orang Jawa yang disebut megengan, yaitu ritual khusus untuk mempersiapkan diri (raga) dalam rangka memasuki bulan Suci Ramadan. Bulan Ramadan yang penuh "rahmat dan ampunan" dalam ajaran Islam tidak akan bisa diraih jika tidak dengan jiwa-raga yang

\footnotetext{
36 Greg Fealy, "Wahab Chasbullah, Tradisionalisme dan Perkembangan Politik NU”, dalam Tradisionalisme Radikal: Persinggungan Nabdlatul Ulama dan Negara, Greg Fealy dan Greg Barton (ed.) (Yogyakarta: LKiS, 1996), 7-8.

37 Thoha Hamim, "Faham Ahlus Sunnah Waljamaah: Proses Pembentukan dan Tantangannya", dalam Kontroversi Aswaja: Aula Perdebatan dan Reinterpretasi, Imam Baehaki (ed.) (Yogyakarta: LKiS, 2000), 155.
} 
bersih, salah satunya dilakukan dengan cara memohon maaf kepada para leluhur melalui tradisi ziarah kubur.

Interaksi Islam dengan nilai-nilai luhur yang terus dijaga dalam budaya masyarakat lokal tersebut pada akhirnya menghasilkan sebuah tradisi keberagamaan populer di lingkungan masyarakat santri Jawa. Fenomena sosio-kultural itu diproduksi melalui kesadaran penuh oleh setiap individu di dalam masyarakat, terutama melalui peran yang dimainkan oleh para elit lokal, seperti kiai-ulama yang mempunyai posisi penting dalam transformasi ajaran Islam di Jawa. Sebagaimana disebut di dalam buku Horikoshi, kiai adalah sosok yang berfungsi atau berperan sebagai penjaga tradisi, ${ }^{38}$ yang dalam kasus masyarakat santri Jawa pada tulisan ini dilakukan dengan cara subordinasi budaya tersebut terhadap nilai-nilai yang berlaku di dalam ajaran Islam. ${ }^{39}$ Penyesuaian secara terus-menerus setiap individu terhadap dunia sosio-kultural yang mereka ciptakan dengan penuh kesadaran itulah yang disebut dengan momen eksternalisasi. Dengan terciptanya tradisi ini, maka mereka secara terus-menerus berada pada proses menemukan diri di dalam dunianya. Mereka menghasilkan dirinya dalam lingkungannya.

Berikutnya, tradisi datang ke makam para leluhur yang fungsi dan maknanya telah mereka tetapkan bersama, dalam waktu yang relatif lama akan selalu diulang-diulang. Tradisi tersebut memberikan satu pedoman dan tata cara hidup bersama pada dunia santri Jawa. Tradisi dengan nilai-nilai luhur di dalmnya menjadi sebuah memori kolektif bagi setiap individu sekaligus dijadikan sebagai bahan pertimbangan ketika mereka melakukan tindakan-tindakan. Tradisi yang disakralkan tersebut akhirnya menjadi bagian integral, yang tidak terpisahkan dalam kehidupan santri Jawa sehingga terjadi apa yang disebut dengan proses pelembagaan. Pelembagaan tersebut menggambarkan terciptanya realitas sosial objektif yang dibentuk melalui produk kultural. Di dalamnya, santri Jawa melakukan interaksi satu sama lain. Produk kultural berupa tradisi ziarah kubur kini telah mendominasi pola pikir dan perilaku mereka. Setiap individu akan merasa bersalah

\footnotetext{
38 Bandingkan fungsi ulama sebagai agen perubahan sosial dalam Hiroko Horikoshi, Kyai dan Perubahan Sosial, terj. Umar Basalim dan Andi Muarly Sunrawa (Jakarta: P3M, 1987), 3.

39 Martin van Bruinessen, NU: Tradisi, Relasi Kuasa, Pencarian Wacana Baru (Yogyakarta: LKiS, 1999), 23.
} 
jika mereka melanggarnya. Inilah yang disebut momen objektivikasi dalam teori konstruksi sosial.

Setelah terjadi proses pelembagaan tradisi ziarah kubur di dalam dunia sosio-kultural santri Jawa, maka proses berikutnya adalah terjadinya proses penyerapan kembali realitas objektif itu ke dalam kesadaran subjektif. Santri Jawa menangkap kembali realitas objektif tersebut sebagai fenomena yang berada di dalam kesadaran sekaligus di luar kesadarannya. Proses penting bagi berlangsungnya aktivitas penyerapan realitas objektif ini terletak pada sosialisasi, yaitu proses yang dipakai untuk proses pengalihan makna tradisi ziarah kubur yang sudah terobjektivikasi dari satu generasi kepada generasi berikutnya melalui program-program yang berlaku di tengah kehidupan bermasyarakat. Individu dengan demikian merupakan produk dari masyarakat. Keberhasilan sosialisasi ini ditandai dengan pengabdian yang dilakukan oleh santri Jawa kepada sistem hidup yang ada di dalam tradisi ziarah kubur. Sistem ini berfungsi sebagai pengendali kesadaran setiap individu di dalam masyarakat. ${ }^{40}$ Pada tataran inilah, terjadi apa yang disebut dengan kesesuaian antara dunia objektif dengan kesadaran subjektif. Nilai yang sudah terobjektivikasi tersebut telah menemukan analognya dalam kesadaran setiap diri santri Jawa.

Pengertian kesadaran santri Jawa yang dibentuk oleh sistem formatif masyarakat bukan berarti sama seperti keberadaan benda yang dibentuk kemudian berlaku pasif dan diam. Sebaliknya, realitas sosial objektif tidak secara pasif diserap oleh santri Jawa, tetapi mereka mengambilnya secara aktif. Setiap individu di dalam masyarakat santri Jawa selain menemukan nilai ziarah yang secara objektif berada di luar dirinya juga menjadi data subjektif di dalam kesadaran. Identifikasi diri secara aktif ini mengisyaratkan terbentuknya individu di dalam masyarakat yang selain ikut memproduk dunia sosial juga memproduk dirinya sendiri. Artinya, identifikasi diri ini merupakan sebuah momen dalam proses yang bersifat dialektis, di mana santri Jawa adalah individu yang diproduk masyarakat melalui proses pentradisian. Di samping itu, masyarakat santri Jawa bukan sosok pasif dan diam, tetapi selalu terlibat dalam proses pengambilalihan kenyataan objektif kemudian dimodifikasi

40 Banca penjelasan yang diberikan oleh Berger tentang agama sebagai sistem kebudayaan yang diartikannya sebagai suatu usaha manusia untuk membentuk kosmos keramat. Lihat Berger, Langit Suci, 32. 
secara kreatif sesuai perkembangan zamannya. Berger dan Luckmann menyebut momen ini dengan istilah internalisasi.

Keseluruhan proses dialektik itu menjelaskan bahwa kesadaran manusia dan struktur bukanlah dua hal yang eksklusif. Artinya, realitas tidak cukup didekati secara struktural. Dengan menunjukkan momen hubungan dialektik ketiga momen, yaitu eksternalisasi, objektivikasi dan internalisasi dalam pola keberagamaan santri Jawa, penulis ingin mengedepankan mekanisme pemberdayaan diri mereka sebagai subjek. Subjek dapat mengolah secara seimbang kebudayaan (balanced absortion of culture) dan menginternalisasikan ke dalam dirinya. Penyerapan budaya objektif yang seimbang dapat berfungsi sebagai seperangkat subjek untuk menciptakan substansi kepribadiannya yang terolah atau termekarkan (cultivated individu). Konsep ini menunjuk kepada kapasitas manusia dalam menyempurnakan kepribadian dengan mengasimilasikan dan menginternalisasi pengaruh-pengaruh eksternal ketika berhadapan dengan wilayah-wilayah personal. Konsep ini sebanding dengan proses aktif deobjektivikasi, ${ }^{41}$ yakni sebuah proses rekonsiliasi bagi kontradiksi internal kebudayaan; rekonsiliasi antara budaya objektif dengan subjektif. ${ }^{42}$

Temuan data tentang bagaimana santri Jawa mengkontruk polapola keberagamaan mereka, dengan pendekatan teori konstruktivis pada tulisan ini, membuka ruang kritik bagi teori-teori sosial yang menggunakan pendekatan struktural-objektivistik untuk melihat polapola keberagamaan yang berkembang di lingkungan masyarakat santri Jawa. Sebab, teori-teori tersebut pada hakikatnya lebih cenderung memiskinkan kenyataan sosial pada dunia sosio-kultural mereka, termasuk meremehkan kemampuan santri Jawa sebagai subjek yang aktif di dalam membangun realitas keberagamaan sesuai dengan zamannya. $^{43}$

41 Deobjektivikasi merupakan konsep yang menjelaskan upaya sadar terhadap pemberdayaan eksistensi subjek melalui refleksi-kritis—atau meminjam istilah kaum post-strukturalis disebut pemikiran kritis-dekonstruktif_-atas nilai dan makna objek. Dalam pengertian yang lebih luas ialah mendudukkan kembali peran subjek sebagai "tuan" atas objek (yang dalam proses sebelumnya berada sebagai tuan dan berlawanan dengan subjek).

42 Bandingkan dengan teori Pierre Bourdieu yang menjelaskan tentang rekonsiliasi antara subjek dan objek dalam George Ritzer-Douglas J. Goodman, Teori Sosiologi Modern, terj. Alimandan (Jakarta: Prenada Media, 2003), 517.

43 Bandingkan dengan pendekatan yang pernah dipopulerkan Anthony Giddens yang mengatakan bahwa pemikiran fungsionalis dan strukturalis adalah 


\section{Relevansi dengan Konsep Pribumisasi Islam}

Dibanding perspektif teori lain, perspektif teori konstruksi sosial yang digunakan di dalam tulisan ini lebih menyuguhkan skema interpretasi lain. Santri Jawa diletakkan sebagai subjek yang dinamis dalam membangun dunia sosio-kulturalnya. Proses terjadinya tradisi populer santri Jawa dalam tulisan ini patut dijadikan sebagai perbandingan kritis bagi teori-teori dalam ilmu sosial, terutama bagi teori yang terbingkai di dalam paradigma fakta sosial yang menempatkan individu di bawah bayang-bayang struktur sosialnya, seperti teori fungsionalisme struktural yang menekankan pendekatan struktural, ${ }^{44}$ agama ditempatkan sebagai fenomena eksternal dan mengedalikan perilaku individu.

Dialektika antara memori kolektif dengan kesadaran santri Jawa, sebagaimana ditemukan selama proses membangun tradisi populer, mengandung pengertian adanya hubungan timbal-balik antara realitas sosial subjektif dengan realitas sosial objektif. Pola keberagamaan seperti ini lebih membuka jalan tengah, di mana santri Jawa dapat menunjukkan potensi dirinya melalui aktivitas yang dihasilkan terusmenerus selama mereka melakukan interaksi yang dilakukan antarsesama di lingkungan sosialnya. Gambaran ini layak dijadikan sebagai sebuah kritik bagi pandangan yang mengatakan bahwa santri Jawa adalah komunitas Islam statis. Bahkan, lebih ironi lagi, santri Jawa dianggap sebagai komunitas yang terkungkung dan tidak dapat keluar dari batas-batas kultural yang diciptakannya sendiri. ${ }^{45}$

Unsur yang melekat dalam tradisi keagamaan populer santri Jawa adalah unsur kreativitas, yaitu terbukanya ruang gerak bagi individu untuk aktif mengkonstruk tradisi keberagamaan populer. Model membangun realitas keberagamaan seperti ini mempunyai kemiripan dengan arus pemikiran yang berkembang dalam kelompok Islam posttradisionalis yang mencoba menggunakan teori-teori sosial kontemporer dalam melihat realitas Islam kekinian. Meminjam istilah

"imperialisme objek sosial" atas subjek, atau tradisi yang memberi prioritas pada struktur (structure) dengan merelativir pelaku (actor). Proyek Giddens ini selanjutnya dikenal dengan teori strukturasi. Lihat B. Herry-Priyono, Anthony Giddens: Suatu Pengantar (Jakarta: Gramedia, 2002), x.

44 Teori ini mempertahankan pandangan sosial yang radikal tentang perilaku manusia sebagai sesuatu yang dibentuk oleh kultur dan struktur sosial. Lihat Ritzer, Sosiologi Ilmu, 25.

45 Zamakhsyari Dhofier, Tradisi Pesantren: Studi tentang Pandangan Hidup Kyai (Jakarta: LP3ES, 1982). 
Ulil Abshar Abdalla, Islam adalah "organisme" yang hidup, bukan monumen mati yang dipahat pada abad ke-7 kemudian dianggap sebagai "patung" indah yang tidak dapat disentuh oleh sejarah kemanusiaan. ${ }^{46}$ Dalam hermeneutika Gadamerian yang biasa dipakai oleh pengamat-pengamat kontemporer, Islam adalah "teks" yang terbuka untuk direproduksi sesuai horizon pembacanya. Masyarakat Islam-termasuk masyarakat santri Jawa di dalamnya—dengan ragam kebudayaannya berada pada posisi sebagai pembaca "teks Islam" sehingga mereka memiliki otoritas penuh di dalam mengkonstruk realitas Islam sesuai dengan konteks kekiniannya. ${ }^{47}$ Pendekatan ini mempunyai kesesuaian dengan jargon populer santri: al-muhâfazah 'alâ al-qadìm al-sâliḥ wa al-akhdh bi al-jadîd al-aslaḥ (memelihara nilai-nilai terdahulu yang sudah baik, dan mengambil nilai-nilai baru yang lebih baik). ${ }^{48}$

Rekonstruksi keberagamaan santri Jawa dalam tulisan ini mempunyai kedekatan dengan konsep Islam pribumi yang pernah dipopulerkan oleh kalangan muda Nahdhatul Ulama (NU) beberapa tahun terakhir, yang mengandaikan pluralitas wajah Islam di tingkat praksis sosial seiring dengan karakter keragaman masyarakat Indonesia. Islam pribumi mempunyai karakter keberislaman yang moderat, progresif, plural, dan apresiatif terhadap keragaman tradisi masyarakat lokal ${ }^{49}$ dengan tidak mengorbankan substansi di dalam ajaran Islam. Gagasan ini menolak proyek otentifikasi yang diinginkan oleh sebagian gerakan Islam radikal di Indonesia yang lebih mengedepankan pandangan-pandangan dunia lebih ekstrim dan kaku (rigid). Sebaliknya, Islam pribumi lebih mengembangkan gagasan keberislaman sesuai budaya masyarakat setempat. ${ }^{50}$

Spirit Islam itu juga mempunyai kedekatan dengan gagasan Islam pribumi yang tidak pernah membunuh tradisi lokal, tetapi

46 Ulil Abshar Abdalla, "Menyegarkan Kembali Pemahaman Islam", Kompas (18 November 2002). Lihat juga Ulil Abshar-Abdalla, Menjadi Muslim Liberal (Jakarta: Nalar, 2005), 3.

${ }^{47}$ Lihat hermeneutika Gadamer yang dikutip Rony Subayu, "Merayakan Pluralisme Islam", dalam http://islamlib.com/id/index.php?page=article\&id=722.

48 Lebih jauh tentang asal-usul kaidah ini dapat dilihat dalam Ahmad Zahro, Lajnah Babtsul Masa'il 1926-1999: Tradisi Intelektual NU (Yogyakarta: LKiS, 2004), 21.

49 Lihat misalnya gagasan yang pernah dilontarkan Khamami Zada, "Menggagas Islam Pribumi”, Media Indonesia (7 Februari 2003).

50 Zuhairi Misrawi, "Menyoal Tradisi untuk Liberasi: Muktamar Pemikiran Islam di NU", dalam http://www.kompas.com/kompas-cetak/0309/26opini/563602.htm. 
mengapresiasinya secara kritis sehingga melahirkan wajah Islam moderat yang berbeda dengan Islam di kawaasan Arab. Meminjam istilah yang dipopulerkan oleh Ulil, gagasan Islam pribumi sebenarnya merupakan bentuk "pembiaran" dan sekaligus "pengakuan" terhadap tradisi lokal yang dipraktikkan oleh masyarakat Islam Indonesia. Penekanan Islam pribumi terletak kepada upaya mengakomodasikan semangat keindonesiaan daripada semangat kearaban. ${ }^{51}$

Rekonstruksi keberagamaan santri Jawa dalam tulisan ini juga mempunyai relevansi dengan gagasan yang pernah dilontarkan kalangan pemikir intelektual Muslim kritis kubu "post-tradisionalisme Islam" yang lebih menekankan pentingnya memperlakukan tradisi agar keberadaannya dapat dijadikan untuk menjawab modernisasi. Upaya ini dilakukan atas dasar pemaknaan tradisi sebagai "sesuatu yang hadir dan menyertai kekinian kita, yang berasal dari masa lalu kita atau masa lalu orang lain, atau masa lalu tersebut adalah masa yang jauh maupun masa yang dekat". Tradisi adalah titik temu antara masa lalu dengan masa kini. ${ }^{52}$ Tradisi bukan merupakan masa lalu yang jauh dari keadaan kita saat ini, tetapi masa lalu yang dekat dengan kekinian kita. Dengan kata lain, jika ada sesuatu yang berkaitan dengan segala sesuatu yang ada di tengah-tengah kita dan menyertai kekinian kita—asal berasal dari masa lalu-maka semuanya merupakan tradisi. Dengan menempatkan tradisi seperti itu, maka memungkinkannya dilakukan rekonstruksi dengan cara menginternalisasikan berbagai pola pemikiran baru.

\section{Penutup}

Pada bagian akhir tulisan ini, penulis bermaksud menyampaikan kesimpulan bahwa rekonstruksi Islam dalam tradisi keagamaan populer santri Jawa dibangun melalui proses dialektik dengan ciri dinamis. Proses ini berlangsung secara terus-menerus dengan tidak memandang remeh masuknya unsur-unsur lokal. Pola demikian lebih mengarah kepada sikap toleran karena memandang Islam bukan sebagai produk akhir (being) yang tidak dapat ditafsirkan kembali di lingkungan mereka. Sebaliknya, Islam dipandang sebagai proses yang sedang terbentuk (becoming) sehingga memungkinkan keterlibatan mereka dalam berperan aktif mengkonstruk realitas keberagamaan sesuai dengan dinamika dan perkembangan zaman.

51 Akhmad Muzakki, “Melintasi Batas Kultur”, Media Indonesia (21 Pebruari 2003).

52 Muhammad Abed Al-Jabiri, Post Tradisionalisme Islam, terj. Ahmad Baso (Yogyakarta: LKiS, 2000), 24. 


\section{Daftar Rujukan}

Abdalla, Ulil Abshar. "Menyegarkan Kembali Pemahaman Islam", Kompas, 18 November 2002.

. Menjadi Muslim Liberal. Jakarta: Nalar, 2005.

Abdullah, Abdul Rahman Haji. "Pemikiran Islam Tradisional di Nusantara: Pertumbuhan dan Perkembangannya", dalam Pemikiran Umat Islam di Nusantara: Sejarah Perkembangannya bingga Abad ke-19. Selangor: Dewan Bahasa dan Pustaka, 1990.

Abdurrahman, Moeslim. "Ber-Islam secara Kultural", dalam Islam sebagai Kritik Sosial. Jakarta: Erlangga, 2003.

Ambary, Hasan Muarif. Menemukan Peradaban Jejak Arkeologis dan Historis Islam Indonesia. Jakarta: Logos Wacana Ilmu, 1998.

Azra, Azyumardi. Pergulatan Politik Islam dari Fundamentalisme, Modernisme, hingga Post-Tradisionalisme. Jakarta: Paramadina, 1996.

Bachtiar, Harsja W. "The Religion of Java: Sebuah Komentar", dalam Clifford Geertz, Abangan, Santri, Priyayi dalam Masyarakat Jawa, terj. Aswab Mahasin. Jakarta: Pustaka Jaya, 1989.

Beatty, Andrew. Variasi Agama di Jawa: Suatu Pendekatan Antropologi, terj. Achmad Fedyani Saifuddin. Jakarta: Raja Grafindo Persada, 1999.

Berger, Peter L. dan Luckmann, Thomas. Tafsir Sosial atas Kenyataan: Risalah tentang Sosiologi Pengetahuan, terj. Hasan Basari. Jakarta: LP3ES, 1990.

-----. Langit Suci: Agama sebagai Realitas Sosial, terj. Hartono. Jakarta: LP3ES, 1991.

Bruinessen, Martin van. NU: Tradisi, Relasi Kuasa, Pencarian Wacana Baru. Yogyakarta: LKiS, 1999.

Dhofier, Zamakhsyari. Tradisi Pesantren: Studi tentang Pandangan Hidup Kyai. Jakarta: LP3ES, 1982.

Fealy, Greg. "Wahab Chasbullah, Tradisionalisme dan Perkembangan Politik NU”, dalam Tradisionalisme Radikal: Persinggungan Nabdlatul Ulama dan Negara, Greg Fealy dan Greg Barton (ed.). Yogyakarta: LKiS, 1996.

Geertz, Clifford. Abangan, Santri, Priyayi dalam Masyarakat Jawa, terj. Aswab Mahasin. Jakarta: Pustaka Jaya, 1989.

------ Islam yang Saya Amati: Perkembangan di Maroko dan Indonesia, terj. Hasan Basari. Jakarta: YIIS, 1982. 
Gibb, H.A.R. Modern Trend in Islam. Illionis: The University of Chicago, 1947.

Hamim, Thoha. "Faham Ahlus Sunnah Waljamaah: Proses Pembentukan dan Tantangannya", dalam Kontroversi Aswaja: Aula Perdebatan dan Reinterpretasi, Imam Baehaki (ed.). Yogyakarta: LKiS, 2000.

Hefner, Robert W. Hindu Javanese: Tengger Tradition and Islam. Princenton: Princenton University Press, 1985.

Herry-Priyono, B. Anthony Giddens: Suatu Pengantar. Jakarta: Gramedia, 2002.

Hodgson, Marshall. The Venture of Islam, Vol. 2. Chicago: The University of Chicago Press, 1974.

Horikoshi, Hiroko. Kyai dan Perubahan Sosial, terj. Umar Basalim dan Andi Muarly Sunrawa. Jakarta: P3M, 1987.

Jabiri (al), Muhammad Abed. Post Tradisionalisme Islam, terj. Ahmad Baso. Yogyakarta: LKiS, 2000.

Misrawi, Zuhairi. "Menyoal Tradisi untuk Liberasi: Muktamar Pemikiran Islam di NU", dalam http://www.kompas.com/ kompas-cetak/0309/26opini/563602.htm.

Morris, Brian. Antropologi Agama: Kritik Teori-teori Agama Komtemporer, terj. Imam Khoiri. Yogyakarta: AK Group, 2003.

Muchtarom, Zaini. Islam di Jawa dalam Perspektif Santri dan Abangan. Jakarta: Salemba Diniyah, 2002.

Mulder, Niels. Agama Hidup Sehari-hari dan Perubahan Budaya, terj. Satrio Widiatmoko. Jakarta: Gramedia Pustaka Utama, 1999.

Muzakki, Akhmad. "Melintasi Batas Kultur", Media Indonesia, 21 Pebruari 2003.

Nata, Abuddin. Metodologi Studi Islam. Jakarta: Raja Grafindo Persada, 2001.

Noer, Deliar. Gerakan Modern Islam di Indonesia 1900-1942. Jakarta: LP3ES, 1980.

Ritzer, George. Sosiologi Ilmu Pengetahuan Berparadigma Ganda, terj. Alimandan. Jakarta: Rajawali Press, 1985.

Ritzer, George-Goodman, Douglas J. Teori Sosiologi Modern, terj. Alimandan. Jakarta: Prenada Media, 2003.

Robinson, Roland. Agama dalam Analisa dan Interpretasi Sosiologis, terj. Achmad Fedyani Saifuddin. Jakarta: Rajawali, 1988. 
Sofwan, Ridin, et al. Islamisasi di Jawa: Walisongo Penyebar Islam di Jawa Menurut Penuturan Babad. Yogyakarta: Pustaka Pelajar, 2000.

Subayu, Rony. "Merayakan Pluralisme Islam", dalam http:/ /islamlib.com/id/index.php?page $=$ article\&id $=722$.

Suryo, Joko. "Tradisi Santri dalam Historiografi Jawa: Pengaruh Islam di Pesisir Utara Jawa”, dalam dari Samudra Pasai ke Yogyakarta, Sunaryo Purwo Sumitro (ed.). Jakarta: Yayasan Masyarakat Sejarawan Indonesia, 2002.

Syam, Nur. "Tradisi Islam Lokal Pesisiran: Studi Konstruksi Sosial Upacara pada Masyarakat Pesisir Palang Tuban Jawa Timur". Disertasi--Universitas Airlangga, Surabaya, 2003.

Woodward, Mark R. Islam Jawa: Kesalehan Normativ versus Kebatinan, terj. Hairus Salim. Yogyakarta: LKiS, 1999.

Zada, Khamami. "Menggagas Islam Pribumi", Media Indonesia, 7 Februari 2003.

Zahro, Ahmad. Lajnah Babtsul Masa'il 1926-1999: Tradisi Intelektual NU. Yogyakarta: LKiS, 2004. 